\title{
Relationship between nursing students' communication skills with Perceived quality of care by elderly patients
}

\author{
Shakerinia $\mathrm{I}^{1}$
}

\begin{abstract}
Introduction and purpose: The aim of this study was to investigate the relationship between nursing students' communication skills and perceived quality of care by elderly patients.

Materials and Methods: Convenience sampling method was used to select 95 female nursing students taking internship in hospitals affiliated with the Rasht University of Medical Science. Data were collected using Queendom Communication Skills Inventory and Irurita Quality Patient Care Scale. Data analysis was done using SPSS version 16 via independent sample t-test as well as Pearson correlation.
\end{abstract}

Findings: Our results showed that students' communication skills significantly differ ( $\mathrm{P}<0 / 01)$ across various age groups. In addition, we found a significant relationship between nursing students' communication skills and perceived quality of care by elderly patients. $(\mathrm{P}<0 / 01)$.

Conclusion: Elderly perception from quality of care is shown to be affected by nurses' communication skills. Therefore, nursing students are recommended to participate in introductory courses and workshops to health communication.

Key words: Communication Skills, Elderly Patient's Satisfaction from Treatment, Nursing Students

Copyright () 2018 Quarterly Journal of Geriatric Nursing.This is an open-access article distributed under the terms of the Creative Commons Attribution international 4.0 International License(http://creativecommons.org/licenses/by /4.0/) which permits copy and redistribute the material, in any medium or format, provided the original work is properly cited.

1 -Associate Professor, Department of Psychology, University of Guilan, Guilan, Iran

(Corresponding Author):E-mail: irajeshakerinia@chmail.ir 


\section{رابطه مهارت هاى ارتباطى دانشجويان يرستارى با كيفيت درمان ادراك شده توسط بيماران سالمند}

'ايرج شاكرى نيا'

تاريخ دريافت مقاله: تأر

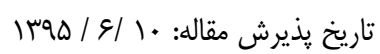

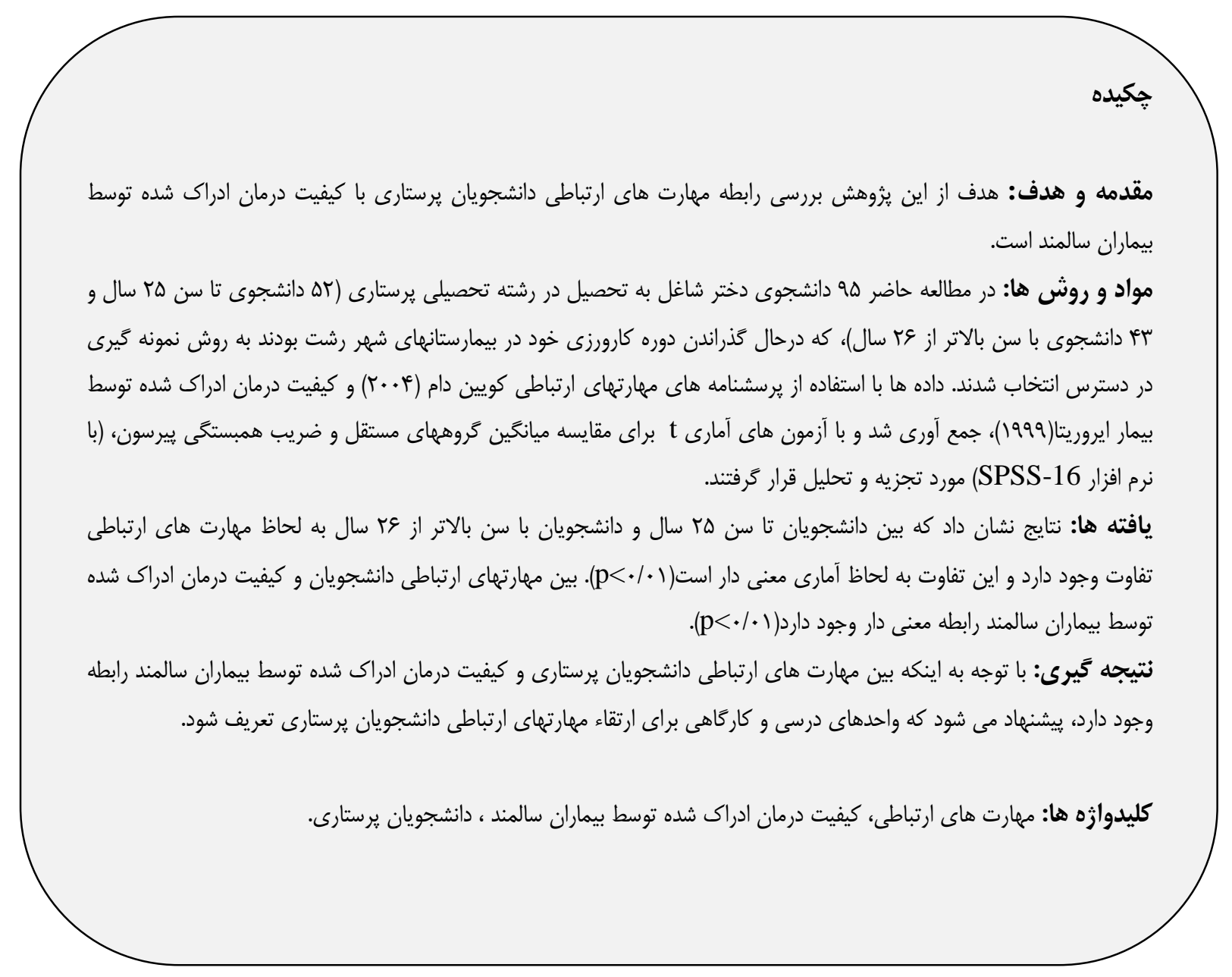

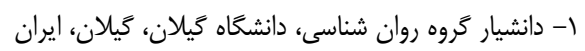

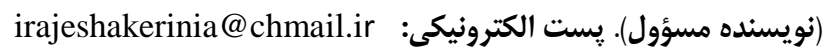


قاسمى، ونكى و معماريان(•)، نيز مراقبـت بـا كيفيـت را حـق تمام بيماران و مسئوليت تمام يرستاران مراقبـت دهنــده قلمـداد كرده اند. حاجى نزاد، رفيعى، جعفر جلال و حقانى(I)، مراقبـت يرستار را يكى از مهمترين جنبه هاى موجود در كار بـالينى مسى دانند؛ Meleis|r()، نيز اجـزاى اصـلى رفتارهـاى مراقبتى در رشته يرستارى را اجراى فنون درمـانى بــه صـورت ماهرانهـه و دقيق، ايجاد ارتباط صحيح بين برستار و بيمار و انتخاب درست كزينه هاى مختلف حين مراقبت و عمل در بـالين بـه صـورت

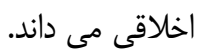
از آنجا كه كيفيت مراقبـت يرسـتارى تحـت تـاثير ارتبـاط بـين يرستار و بيمار، شركت فعالانه بيمار در امر تصـميم گيـرى مسى باشد(سا)، در اين زمينه توجه به ديدكاه بيماران، عامل مهمى در زمينه برنامه ريزى در جهت ارتقاى كيفيت تلقى شده است(If). هم هُنين با توجه به نقش يرستار بعنوان كليـدى تـرين عضـو ارتقاى كيفيت در زمينه ارائه مراقبتها و اهميت رضايت بيماران بعنوان يكى از شاخصه هاى مهم كيفيت خـدمات(ه()، جهـت وضوح هرجه بيشـتر مفهـوم كيفيـت و تـاثير بهتـر مراقبتهـاى يرستارى بايد نظرات بيماران و يرسـتاران مــد نظـــر قـرار كيــدد. هرجند ممكن است در برداشـت مفهـوم كيفيـت مراقبـت بـين ديدكاه يرستاران، يزشـكان و بيمـاران همخَامى كـاملى وجـود نداشته باشد(ع). بنا بـراين يـك جنبـه مهـم از مراقبـت هـاى يرستارى ارتباط با بيماران است. وظايف اصلى يرستاران نه تنها اطلاع رسانى در باره بيمارى و درمان اسـت، بلكـهـ ايجـاد يـــ رابطه درمانى موثر به وسيله بررسى نكَرانى هاى بيماران، درك، همدلى و فراهم كردن آسايش و حمايـت آنـان مس باشـد(IV). بسيارى از وظايف برستاران نظير مراقبتهاى جسمانى از بيماران،
مراقبت و كيفيت مراقبت و خدمات ارائه شــده بـراى بيمـاران و نيازمندان، به ويزه سالمندان، همواره بخشى مهـم و اساسى در حوزه خدمات بهداشتى و درمانى محسوب مى شود، اين موضوع هرجِند همواره مد نظر بوده ولى در برهـهـ هـايى از زمـان مـورد توجه بيشترى واقع شده است؛ از جمله زمانهايى كه ايـن بحـث توسط متخصصين فن، مورد توجه قـرار گَرفت، سـالهاى دهـــ •199 و •190 بـود؛ اخيـراً نيـز موسسـات مراقبـت بهداشـتى، شناسايى ارزش كيفيت مراقبت را مد نظر قـرار داده انـد(ا). بـه

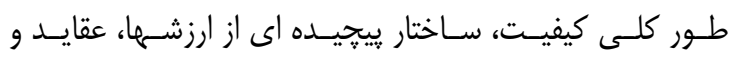
نكَرشهاى افرادى است كه در نظام مراقبتهاى سلامتى در تعامل با يكديخرند(T). به همين علت ارائه مراقبتها و خدمات با كيفيت مناسب در نظام خــدمات بهداشـتى درمـانى بــهـ ويـزه در زمينـهـ خدمات يرستارى يك اولويت مهم است(ب)؛ به طورى كه درجـه بندى و اعتبار بخشى بيمارستانها، در اغلب كشورها، تحت تـاثير مراقبتهاى برستارى و كيفيت آن است(")، شايد به همين دليـل است كه در بين كليه مراقبتهاى ارائه شده در محيطهاى درمانى

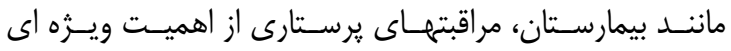
برخوردار است(هو ). يرسـتارى حرفـه اى يِيجيـده و حرفـه اى عمدتاً عملى است(V). فعاليتهاى برستاران داراى ابعـاد بسـيارى است كه با تأكيد بر جنبه هاى مختلف مراقبتهاى برستارى و نقش آنهاست، مثـل مراقبتى، حفـاظتى، مــيريتى، آموزشى و ارتباطى كه يرستار اغلب همزمان در نقش هاى مختلـف عملـ

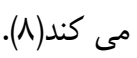
 يرسـتارى دانستها، كيفيـت مراقبـت و جلـب رضـايت مراقبـت شوندًان را از اهداف آن ذكر كرده اند. در همين رابطه يورفرزاد 
كنند، بسيار كم است، كفتخو با بيمار بسيار سطحى و اغلب در رابطه با مشكلات جسمانى اوست و به جنبـهـ روانسى مراقبـت كمتر توجه مى شود(9؟). در مطالعه اى كه رفتارهاى ارتبـاطى دانشـويان يرسـتارى را مـورد بررسى قـرار مسى داد، Hegedus دوره ارتباط مطلوب داشـتند ولى در پايـان دوره، بـهـ برقـرارى

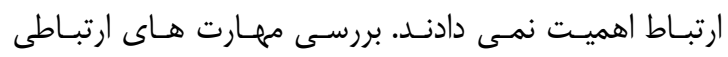
دانشجويان يرستارى در بخشهاى مختلف يك بيمارستان نشان داد كه دانشجويان از مهارت كافى در اين زمينه برخوردار نبوده و تنها ضمن ارائه خدمات بـا بيمـاران ارتبــاط داشـته انـد(آ).

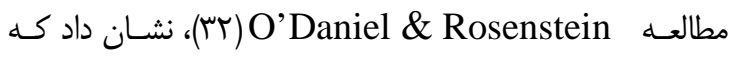
تعامل نامناسب بيماران و يرستاران، باعث بروز استرس، احساس ناميدى و از دست دادن تمركز، كاهش همكارى، كاهش انتقال اطلاعات، اختلال در برقرارى ارتباط و مختل شدن روابط بـين بيماران و كادر درمانى مى شود. از جمله بيى آمدهاى ناتوانى در برقرارى ارتباط مطلوب بين يرستاران و بيماران، احسـاس عـدم رضايتمندى بيماران از درمان و بدنبال آن تضعيف اعتمـاد بـين يرستار و بيمار است. در اين ميان توحه به سـالمندان از اهميـت بيشترى برخوردار است(سب). با توجه بــه مطالـب فـوق وكمبـود يزوهش در اين زمينـه در ايـران، محقـق بـراى بررسى رابطهـه. مهـارت هـاى ارتبــاطى دانشـجويان يرسـتارى بـا رضـايتمندى بيماران سالمند از درمان و همجنين بررسى اين نكته كه آيا بين دانشجويان بــه لحـاظ مهارتهـاى ارتبـاطى تفــاوت وجـود دارد؟ تحقيق حاضر را انجام داد.
حمايت هاى روان شناختى و تبادل اطلاعات بـا بيمـاران بـدون

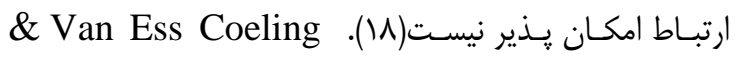

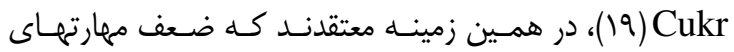
ارتباطى مى تواند بـر عملكـرد برسـتاران تـأثير منفى بحــارد. تحقيقات نشان مى دهد كه آموزش و به كـارگيرى مهـارت هـا ارتباطى توسط يرستاران، نه تنها باعث يِيدايش برخى از تغييرات مثبت در شرايط بالينى بيمـار خواهـــ شــ، آمـوزش مهارتهـاى ارتباطى به برستاران مى تواند به آنها كمى كند تا از اشتباهانى كه در تعاملاتشان با بيماران به وقوع مى ييوندد، آكًاه تر باشند و مهارتهاى ارتباطى شان ارتقاء يابد (·r). در حال حاضر افزايش سطح خدمات فوريتى، حجم كارى زياد و كمبود تعداد يرستاران، تأثير بـهـ سـزايع بـر كيفيـت مراقبتهـاى

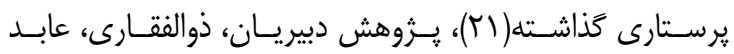
صيادى، علوى مجد(T)، نشان داد كه خـدمات يرسـتارى اراده شده به بيماران نتوانسته تأمين كنتــه خواسـته هـا و انتظـارات بيماران باشد؛ به همين جهت نكَرانى هايى را در جامعه يرستارى در خصوص ايمنى بيماران و كيفيت مراقبتهـا در بيماستان هـا

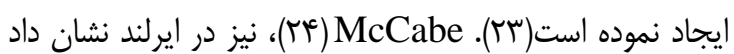
كه بيماران از فقدان ارتباط مناسب، احساس عدم توجه ، همدلى و ارتباط دوستانه از طرف برستاران گكله مند و ناراضسى هستتند. براى آن كه برستاران بتوانند بنحو مطلوبى خـدمات حرفـه اى خود را ارائه دهند، لازم است كه بتواند ارتباط مناسب با بيمار و خانواده وى، يزشكان، ساير برستاران و اعضاى تيمه درمـانى و مراكز درمانى برقرار كنند(؟ه). نتـايج يـزوهش هـاى مختلـف انجام شده در اين زمينه نشـان داده كـه توفيـق يرسـتاران در ارتباط با بيماران و خانواده آنان كافى نبوده است(عr، YT و ^ץ). بعنوان مثال مدت زمانى كه برستاران صرف ارتباط با بيمار مى 


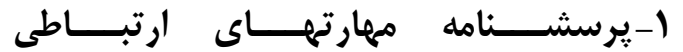

\section{$(\uparrow++\varepsilon)$ Queendom}

در يزوهش حاضر از آزمون مهارت ارتباطى نسخه تجديـــ نظـر شده به عنوان ابزار جمع آورى اطلاعات استفاده شد. اين آزمون كه توسط Queendom(ع (r)، براى سنجش مهارتهاى ارتباطى بزركسـالان ابـداع شــه داراى ثب عبارت(كويـه) اسـت كـه مهارتهاى ارتباطى را مورد سنجش قرار مى دهد. براى تكميـل آن پِاسخكَو بايد هر كَويه را بخوانـد و سـبس ميـزان انطبـاق وضعيت فعلى خود را با محتواى آن بر روى يك طيف ليكرت ينج درجه اى از I (هركز) تا ه (هميشه) مشخص كنـد. دامنـهـ محتمل براى هر فرد بين عآ تا • rا خواهد بود. لازم به ذكر است كه بـالا بـودن نمـره مقيـاس بـهـ منزلـه ضـعيف بـودن مهارتهاى ارتباطى فرد است. بإيـايى ايـن آزمـون در تحقيقـات

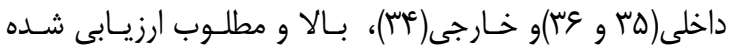
است. در جدول ا برخى از كويه هاى اين برسشنامه ارائه شـده
مواد و روش ها - ماد

اين يزوهش يك مطالعه توصيفى - مقطعى است كه بر روى ه9 دانشجوى دختر شاغل به تحصيل در رشته تحصيلى يرسـتارى (انشجو در محدوده سنى 19 تا هT سال - و بא دانشجو در محدوده سـنى ع سـال و بـالاتر)، كهـ درحـال كذرانـدن دوره كارورزى خود در بيمارستانهاى شهر رشت بودند و همين تعـداد بيماران مسن مونث اجرا شد. روش كار بدين ترتيـب اسـت كـهـ يرسشنامه مهارتهـاى ارتبـاطى توسـط دانشـويان يرسـتارى و يرسشنامه كيفيت درمان ادراك شده، توسط بيماران دانشجويان يرستارى تكميل شدند. روش نمونه كيرى نيز به صورت نمونـهـ كيـرى در دسـترس اسـت و بـراى همخنس بيشـتر مشـاركت كندكًان در يزوهش، تلاش شد تا قرابت مولفه هاى تحصيلى و طبقه اقتصادى و اجتماعى مشاركت كنندكان در تحقيق در نظر كَرفته شود. در يزوهش حاضر از دو يرسشنامه اسـتفاده كرديـده

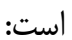

جدول ا برخى از تَويه هاى يرسشنامه مهارتهاى ارتباطى كوئين دام (ع + + )

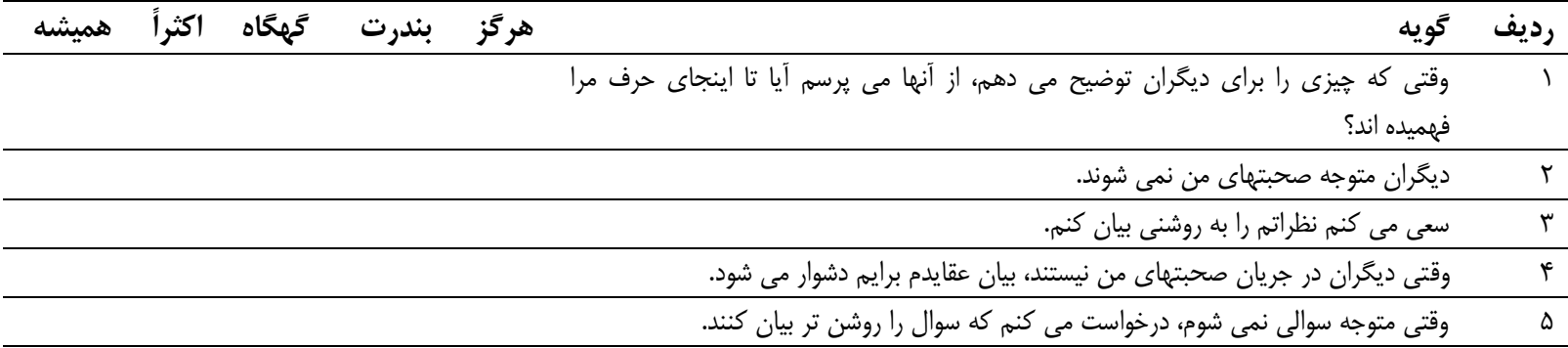

مقياس كيفيت درمان ادراك شده توسط بيمـار، جهـت بررسى فرآيند مراقبـت و كيفيـت مراقبـت يرسـتارى از سـال I9VD در كشورهاى آمريكا، انغخلستان و نيجريه مورد استفاده قـرار گرفتـهـ است(rV). ايـن مقيـاس شـامل ץ بخـش مشخصـات فـردى- r- مقياس كيفيت درمان ادارك شده توسـط بيمـار (1999) 'Irurita 1 - Quality Patient Care Scale(QUALPAC) 
رئيس دانا، قربانى و صادقى(1)، نيز پايايى اين مقياس از طريق

همسانى درونى و با استفاده از ضـريب آلفــاى كرونبـاخ •^/•و

مطلوب تشخيص داده شد. در جدول بَ برخى از گَيه هاى گويه هاى مقياس كيفيت مراقبت از بيمار در بعد روانى اجتماعى و در جدول أ برخى از كويه هاى كَيه هاى مقياس كيفيـت درمـان ادراك شده توسط بيمار در ابعاد روانى اجتماعى و ارتباطى ارائهـ

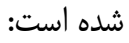

جدول "َ برخى از تويه هاى مقياس كيفيت مراقبت از بيمار در بعد روانى اجتماعى نئى

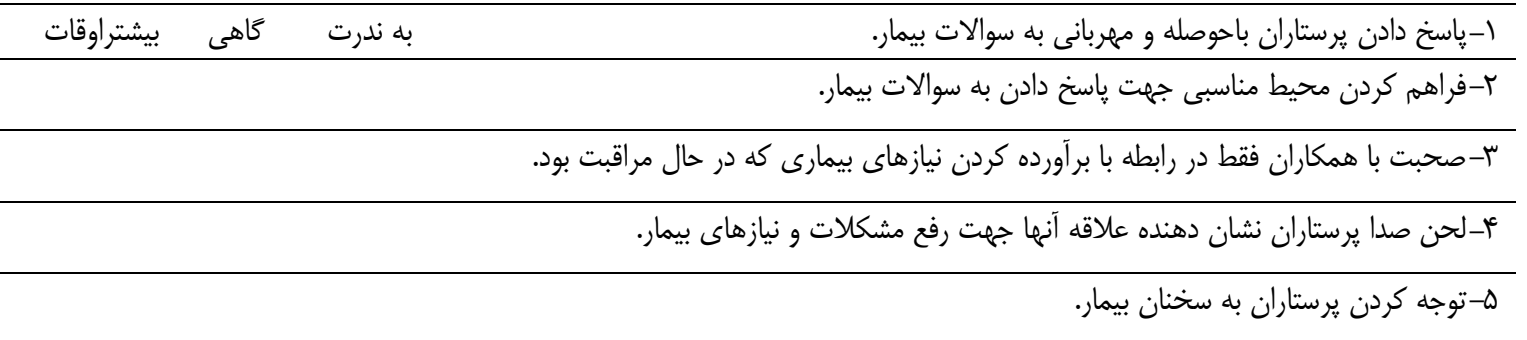

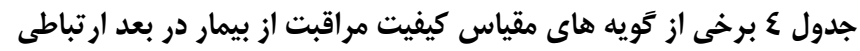

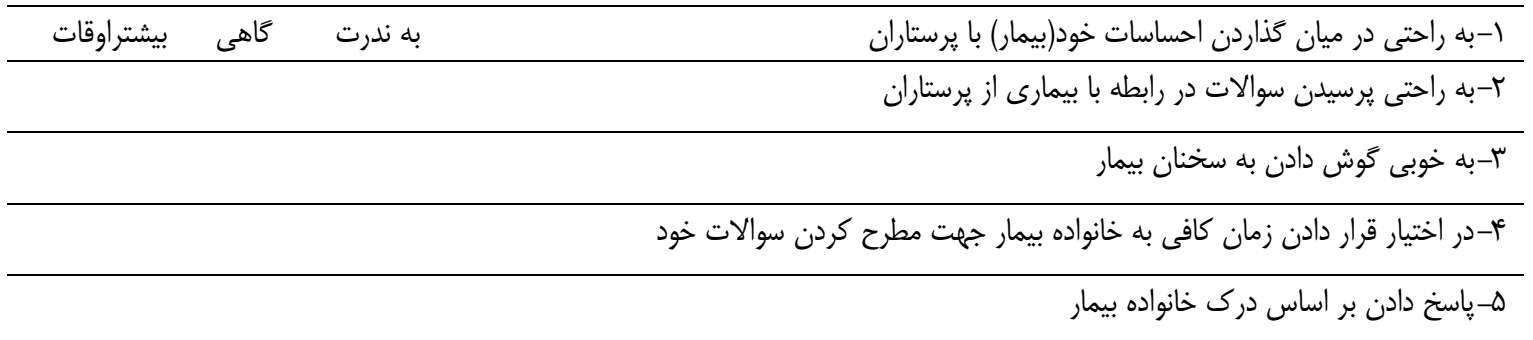

اجتماعى(شامل • (1 سوال)، روانى - اجتماعى شامل Y سـوال و ارتباطى(شامل سا سوال) در طيـف ليكـرت بـه نــدرت، گَاهى،

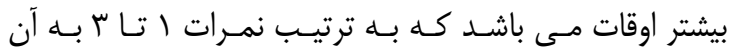
اختصاص يافت. با محاسبه ميانخين نمـرات مقيـاس برسشـنامه براى هر فـرد، نظـرات در ب گَروه نـامطلوب (كمتـر ازه/1) تـا

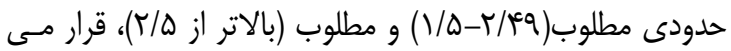
كيرند. اين مقياس توسط حقيقى خوشخو (ب)، مورد بررسى قرار كَرفته، با فرهنَ ايران تطبيق داده شد. درمطالعـه نيشـابورى،

يافته ها

و به همين تعداد بيماران مسن مونـث انجـام شـــ. در جـدول هـ

ميانكَين و انحراف معيار نمـرات مهارتهـاى ارتبـاطى و كيفيـت

درمان ادراك شده توسـط بيمـار (در ابعـاد روانى- اجتمـاعى و ارتباطى)، ارائه شده است. 
جدول ه ميانكَين و انحراف معيار نمرات مهار تهاى ارتباطى و كيفيت درمان ادراك شده توسط بيمار (در ابعاد روانى- اجتماعى و ارتباطى)

\begin{tabular}{|c|c|c|c|}
\hline انحر اف معيار & 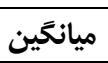 & متغير & متغير \\
\hline$r / \cdot q$ & Ir. & يرستار تا سن فT سال & مهارتهاى ارتباطى \\
\hline $1 / 1$. & 111 & يرستار بالاتر از عץ سال & ميهارتهاى ارتباطى \\
\hline $1 / \mathrm{VV}$ & Df & تحت مراقبت يرستار تا ro سال & كيفيت درمان ادراك شده توسط بيمار در بعد روانى- اجتماعى \\
\hline$r / \cdot \Lambda$ & gr & تحت مراقبت يرستار بالاتر از عץ سال & كيفيت درمان ادراك شده توسط بيمار در بعد روانى- اجتماعى \\
\hline $1 / \Delta F$ & r) & تحت مراقبت يرستار تا To سال & كيفيت درمان ادراك شده توسط بيمار در بعد ارتباطى \\
\hline I/A & ru & تحت مراقبت يرستار بالاتر از عץ سال & كيفيت درمان ادراك شده توسط بيمار در بعد ارتباطى \\
\hline
\end{tabular}

هاى مستقل استفاده شد كه نتيجه آن در جــدول ع ارائهـ شــده ست.
همانطور كه در جدول ه مشاهده مى شود دانشجويان تا سن DQ سال از مهارتهاى ارتباطى كمترى برخوردارند. در عين حال براى اينكه مشخص شود كه آيا تفاوتهاى موجـود بــه لحـاظ آمـارى معنى دار هستند نيز از آزمون t براى مقايسه ميانگينهـاى گَروه

جدول 7 مقايسه ميانكَين متغير هاى مهارتهاى ارتباطى و كيفيت درمان ادراك شده توسط بيمار (در ابعاد روانى- اجتماعى و ارتباطى) در

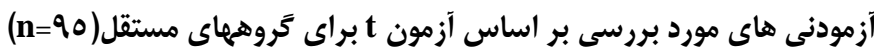

\begin{tabular}{|c|c|c|c|c|c|c|}
\hline sig & درجه آزادى & $\mathbf{t}$ & تفاوت ميانگين & ميانَين & متغير & 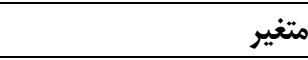 \\
\hline \multirow[t]{2}{*}{$.1 \cdot+1$} & \multirow[t]{2}{*}{ १พ } & \multirow[t]{2}{*}{$V / \wedge \varepsilon$} & \multirow[t]{2}{*}{ IV } & Ird & يرستار تا سن ف سال & \multirow[t]{2}{*}{ مهارتهاى ارتباطى } \\
\hline & & & & 111 & يرستار بالاتر از عץ سال & \\
\hline \multirow[t]{2}{*}{$.1 \cdot+1$} & \multirow[t]{2}{*}{ q } & \multirow[t]{2}{*}{ ع } & \multirow[t]{2}{*}{$-\wedge$} & $\Delta F$ & تحت مراقبت يرستار تا هT سال & \multirow{2}{*}{ 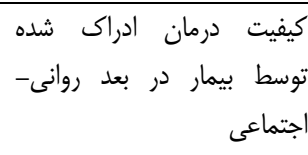 } \\
\hline & & & & gr & تحت مراقبت يرستار بالاتر از عץ سال & \\
\hline \multirow[t]{2}{*}{$.1 \cdot \cdot 1$} & \multirow[t]{2}{*}{ q } & \multirow[t]{2}{*}{$4 \% .9$} & \multirow[t]{2}{*}{$-\gamma$} & r) & تحت مراقبت يرستار تا Tه سال & \multirow{2}{*}{ كيفيت درمان ادراك شده بيمار در بعد ارتباطى } \\
\hline & & & & ru & تحت مراقبت يرستار بالاتر از عץ سال & \\
\hline
\end{tabular}

براى بررسى رابطه مهارتهـاى ارتبـاطى دانشـجويان و كيفيـت درمان ادراك شده بيماران(در ابعاد روانى - اجتماعى و ارتبـاطى) از ضريب همبستخى ييرسون استفاده شد كه نتايج آن در جدول

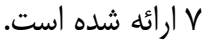

همانكَونه كه در جدول 9 مشـاهده مسى شـود تفـاوت ميـانخين مهارتهاى ارتباطى دانشجويان، معنى دار است. همجنــين تفـاوت هاى موجود در ميانخين كسب شده توسـط بيمـاران در نمـرات كيفيت درمان ادراك شده(در ابعاد روانى- اجتمـاعى و ارتبـاطى) نيز با توجه به خدمات دريافت توسط دانشجويان معنى دار است. 
جدول V رابطه مهار تهاى ارتباطى و كيفيت درمان ادراك شده توسط بيمار (در ابعاد روانى- اجتماعى و ارتباطى) در برستاران مورد

بروسى(n=90)

\begin{tabular}{|c|c|c|c|}
\hline كيفيت درمان ادراك شده بيماران & كيفيت درمان ادراك شده بيماران در & مهار تهاى ارتباطى & متغير \\
\hline & & 1 & \\
\hline & 1 & $-\cdot / V \Delta \Delta$ & \\
\hline 1 &.$/ 95$ & $-\cdot / N G$ & \\
\hline
\end{tabular}

روانى - اجتماعى و ارتبـاطى منفى معنى دار و رابطـهـ كيفيـت درمان ادراك شده بيماران در ابعاد روانى - اجتمـاعى و ارتبـاطى مثبت معنى دار است.

-نتايج نشان داد كه بيماران سالمند مشاركت كننده در ي-رزوهش خدمات دريافتى از دانشـجويان را متفـاوت ارزيـابى كـرده انـد، تفاوتى كه به لحـاظ آمـارى معنى دار شــه اسـت. در بررسى تحقيقات انجام شده در زمينه مهارتهاى ارتباطى، سـن همـواره

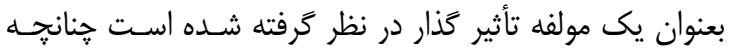
افزايش سن موجب افزايش تجربه، بلوغ فكرى، تقويـت صـبر و حوصله افراد خواهد شد. بعنوان مثال متحديان تبريزى، همدانى

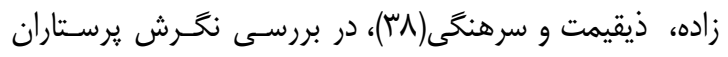
نسبت به ارائه مراقبتهاى جسمى از بيماران سالمند دريافتند كهـ هر اندازه بر سن برستاران افـزوده مسى شـود بـر كيفيـت ارائـه خدمات به بيماران سالمند افزوده مى شود. -بين مهارت هـاى ارتبـاطى دانشـجويان يرستارى بـا كيفيـت درمان ادراك شده توسط بيمار رابطه مثبت معنى دار وجود دارد. در تحليل اين يافته مى توان كفت كـهـ از جملـه نتـايج ارتقـاء مولفه مهارت هـاى ارتبـاطى و توانايى در برقـرارى ارتبـاط بـاــا

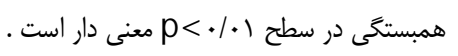

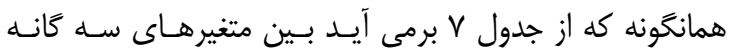
تحقيق رابطه معنى دار( •|+> p) وجود دارد. رابطه مهارتهاى ارتباطى دانشجويان و كيفيت درمان ادراك شده بيماران در ابعاد

\section{بحث و نتيجه كيرى}

ارائه خدمات مطلوب بجداشتى و درمانى توسط كادر مربوطه كه. يرستاران جزء مهمترين آنها هستند، براى بيماران حـائز اهميـت فراوان است. امروزه سيستمهاى ارائه دهنده اين خـدمات يعنى بيمارستانها و مراكز بهداشت و درمان، تنهـا بـهـ فـراهم آوردن و ارائه ايـن امكانـات اكتفـا نمسى كنـــ، بلكـهـ در كنـار آنهـا بـهـ موضوعات انسانى مخصوصاً مولفه هاى روان شناختى نيز توجـهـ ويزه دارند. جنانكه Perry \& Potter) (^ر همـين رابطـهـ اذعان مى دارد كه مراقبت يرستارى با هدف بهبودى و سـلامت مددجو، نه تنها به نيازهاى جسمى مددجو توجه دارد، بلكه كليـه نيازهاى عاطفى، روحى و اجتماعى مـددجو را نيـز در بـر مى كيرد. اين مولفـه هـاى متـــوع روان شـناختى نظيـر مهارتهـاى ارتباطى، نوع دوستى، از خود كذنشتخى، صبر و حوصـله و نظـاير اينها معمولاً از هزينه زيادى برخـوردار نبـوده، در صـورت ارائه مطلوب، از تأثير گزارى بالايى نيز برخوردارند. با توجه به مطالب ارائه شده، نتايج زير از تحقيق حاضر بدست آمد: 
Pumarporn Nuntasupawat ،Chontawan ، \& (با)، دريافتند كه كيفيت مراقبت يرسـتار، بـه ارتبـاط بـين يرستار و بيمـار بستـتى دارد و در بركيرنــده اطمينـان از ارايـهـ

مراقبت هاى همه جانبه به بيمار مى باشد. همحنين Morse ، Johnson \& Bottorff ، Neander SSolberg (أ)()، مراقبت را يكى تعامل انسانى، يك مداخله درمـانى، يـك عمل اخلاقى، يك تأثير متقابل و يك ويثگى انسانى مى داند. با توجه به كَستردىى، اهميت و نفـوذ نقـش يرسـتاران در ارائهـ. خــدمات مطلـوب درمـانى، امـروزه آمـوزش مولفـهـ هـاى روان شناختى به كادر درمـان على الخصـوص برسـتاران از اهميـت زيادى برخودار است و در سرفصلماى آموزشى يرستاران ديـده شده است. اين دانشجويان از جمله كَروه هـايى هسـتند كـه از طريق آموزش هاى لازم، مهارت هاى انسانى و ارتباطى فوق را ياد مى كَيرند. آموزش اين مهارت ها تأثير بسزايى در عملكـرد آنان داشته و تأثير آن را در ميزان رضـايت بيمـاران مسى تـوان مشاهده كـرد(ץ؟). بـا توجـهـ بــه اهميـت برقـرارى ارتبــاط در يرستارى، ضرورى است كه يرسـتار مهـارت خـود را در زمينـهـ برقرارى ارتباط افزايش دهد. وظيفه يك يرستار برآورده ساختن نيازهاى بيمار از طريق ارتباط مؤثر است و اين امر زمانى امكان يذير است كه اطلاعات كافى در اين زمينه داشته باشـد. عـدم آكاهى كافى مى تواند منجر به عدم موفقيت در ارائه خـدمات

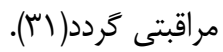
به نظر مى رسد مهارت هاى ارتباطى بيمارمحور، نيازمند توجه خاص بوده و ضرورى است كه در اين رابطه تدابير لازم انجام كيرد(آب). نظر به اينكه ارتباط خوب بين يرسـتاران و بيمـاران هسته اصلى مراقبت از بيمار است، برنامه هاى آموزشى در اين زمينه بايد با تمرينات بالينى هماهنگى داشته و در راستاى كار
بيماران، افزايش درك نيازهـاى روان شــاختى بيمـاران توسـط يرستاران است. فرد موفق در برقرارى ارتباط احساس مس كنـــ

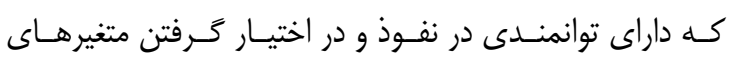
محيطى است كه خود منجر به رشد اعتماد به نفس است. آثار و تبعات اين اعتماد به نفس در تقويت روحيـه مشـاركت و تعامـل برجسته مى شود و مى توانـــ همجنــان در تقويـت ايـن روحيـهـ عمل كند و منجر بـهـ ارائهـ خــدمات بهتـر و مناسـب تـر شـود. تحقيقات زيادى در حوزه روان شناسى ارتباطات، با ايـن نتيجـهـ گيرى همخوان است بعنوان مثال White (qَ)، معتقد است به تدريج كه دانشجويان در محيط بالينى موفق به كسب اعتماد به نفس مى شوند، درك بيشترى از محيط بالينى خواهنــد داشـت؛ خودشان را بهتر به عنوان يرستار درك خواهند كـرد و قـادر بـهـ عملكرد مستقل و تمركز بهتـر بـر روى بيمـاران خواهنــــــود. Smith \& Gray دانشجويان در برنامه هايشان ييشرفت مى كنتـد فاصـله آنهـا از راهنماهايشان به تدريج كم مى شود. اين حركت از وابستىى به سمت استقلال ييشرفتى در اعتماد به نفس، مهارت ها و ديدكاه يادكيرنده از مراقبت ها را نشان مى دهـــ. تحليـل ديخــى كـهـ. براى اين يافته مى توان ارائه داشت اين است كه آنجهه مـا بـين بيمار و يرستار مى كذرد در برتو ارتباطات انسانى معنى مى يابد، لذا زمانى كه يرستار خدمات خود را با اصـول ارتباطـات انسـانى آميخته مى سازد و به بيمار عرضه مى كند شـيرينى و حسلاوت موجود درآن باعث مى شود تا اثربخشى آن هُندين برابر شـود و خدمتى كوجى از سوى يك يرستار، در نظر يك بيمار (سـالمند نيازمند)، تحفه اى بزرگ ارزيابى شود. تحقيقات زيادى با نتيجه

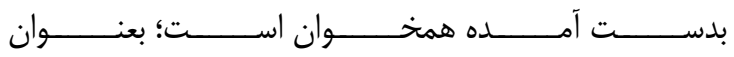

مثــالAnders ، Kunaviktikul 


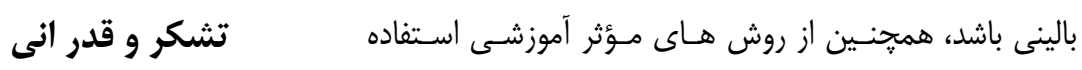

$$
\begin{aligned}
& \text { محقق وظيفه خود مى داند از همـه دانشـجويان يرسـتارى كـهـ } \\
& \text { زمينه انجام اين تحقيق را فراهم كرده اند تقدير و تشـكر بعمـل }
\end{aligned}
$$

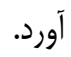

- References

1. Ghamari Zare Z, Anoosheh M, Vanaki Z, Hajizadeh E. Impact on quality of nursing records peer review process. Shahid Beheshti University College of Nursing and Midwifery 2008; (61): 18. [Persian].

2. Gunther M. and Alligood MR. A discipline-specific determination of high quality nursing care. J Adv Nurs 2002; 38:353-359.

3. Haghighi Khoshkhoo N. Quality nursing care by nurses in the hospitals of Tabriz. Tabriz University of Medical Sciences thesis. 2004. [Persian].

4. Moussawi R, Mousavi A, Foroogi S, Zakati R, Mahdian Nasab S. Hossein Abbasi N. Performance management in nursing, Tehran: Ashura. 2007. [Persian]

5. Akbari Sh. Barriers continuous development of quality nursing care from nurses in teaching hospitals of Tabriz University of Medical Sciences. Tabriz University of Medical Sciences thesis.2002. [Persian].

6. Pazargadi M, Tafreshi MZ, Abedsaeedi Z, Majd HA. And Lankshear AJ. Indicators for the development of nursing care quality in Iran. Int Nurs Rev 2008; 55: 399-406.

7. Zareian Jahromi A, Ahmed F. Learning Needs Assessment in Bachelor of Nursing: A Qualitative Study. Journal of Medical Science 2005; 5 (2-14): 81-92. [Persian].

8. Potter P, Perry A. Fundamentals of Nursing. vth edition. Philadelphia: Mosby; 2009.

9. Lewis KE, Woodside RE. Patient Satisfaction with Care in the Emergency Department. J Adv Nurs 2009; 17(8): 959-64.

10. Purfarzad Z, Vanaki Z, farmahinifarahani, M, Ghamarizare Z, sacrifice M. Check leadership style adaptability nurse educators, clinical training 2012; 1 (1-1): 59-65. [Persian]. 
11.Haji Nejad ME, Rafieei F, Jafar Jalal E, Haqqani H. The relationship between nurse caring behaviors from patients' perspectives of patient satisfaction. Iran Journal of Nursing 2007; 20 (49): 73-85. [Persian].

12. Meleis AI. Theoretical nursing: Development and progress. זth ed. Philadelphia: Lippincott Williams \& Wilkins 2007.

13. Merkouris A, Papathanassoglou ED. and Lemonidou C. Evaluation of patient satisfaction with nursing care quantitative or qualitative approach. Int J Nurs Stud 2004; 4(41):357361.

14. Asefzadeh S. Rezazapoor A. management of health and medicine. Qazvin: University of Medical Sciences. [Persian].

15. Sydnzhad A. Satisfaction of emergency department patients and staff. Paper presented at the First Congress of the development of quality in the emergency department. Tehran. Iran. 2002. [Persian].

16. Shannon SE, Mitchell PH. Cain KC. Patients, Nurses, and Physicians Have Differing Views of Quality of Critical Care. J Nurs Scholarsh 2002; 34: 173-179.

17. Vanaki Z. Support satisfaction in nursing and its effect on cancer patients undergoing chemotherapy. Thesis Medicine, Tarbiat Modarres University, Tehran. 2002. [Persian].

18.Fakhr Movahhedi A, Salsali M, Negarandeh R, Rahnavard, Z. Underlying factors in the nurse-patient relationship: a qualitative study. Koomesh 2011; 13 (1-41): 23-35 [Persian].

19. Van Ess Coeling H, Cukr PL. Communication Styles That Promote Perceptions of Collaboration, Quality, and Nurse Satisfaction. Journal of nursing care quality. 2000; 14(2): 63-74.

20. Farmahini Farahani M, Kashaninia Z, Hosseini, MA, Biglarian, A. The effects of teaching communication skills to nurses on patients' satisfaction with the way communication. 0.1 Nursing Research 2006; (3): 47-41. [Persian].

21. Long LE. Imbedding quality improvement into all aspects of nursing practice. Int $\mathbf{J}$ Nurs Pract 2003; 9(5): 280-4.

22. Dabirian A, Zulfikar, H, Abed Saeedi, J, Alavi Majd, H. Quality of patient care from the perspective of AIDS patients in teaching hospitals affiliated to Shahid Beheshti University of Medical Sciences and Health Services, Tehran. Journal of Nursing, Midwifery 2008; 18 (61): 40-46. [Persian].

23. Kunaviktikul W, Anders RL, Srisuphan W, Chontawan R, Nuntasupawat R, Pumarporn O. Development of quality of nursing care in Thailand. J Adv Nurs 2001; 36(6): 776-84. 
24. McCabe C. Nurse-Patient Communication: an Exploration of Patients' Experiences. J Clin Nurs 2004; 13(1):9-41.

25. Moradi M, Goudarzi, A. Community foundations in nursing. Tehran: shakheh 1999. [Persian].

26. Shekani, J. Satisfaction of parents of hospitalized children how to communicate with their employees in a teaching hospital in the city of Rasht. Master thesis. Tehran: Nursing and midwifery. Shahid Beheshti University of Medical Sciences 2008. [Persian].

27. Kotecki CN. Baccalaureate nursing students' communication process in the clinical setting. J Nurs Educ 2002; 41(2): 8-61.

28. Spears LA. Writing business communications: are nurse managers prepared? Nurs Manage 1997; 28(12); 5-43.

29. Wilkinson S. Factors which influence how nurses communicate with cancer patients. J Adv Nurs 1991; 16(6): 677-88.

30. Hegedus KS. From case study to plans for caring. West J Nurs Res 1991; 13(5): 653-7.

31. Browning EM, Campbell ME. Evaluating students' communication skills: tape recording. Nurse Educ. 1987; 12(1): 9-28.

32. Rosenstein AH, O'Daniel M. Impact and implications of disruptive behavior in the perioperative arena. Journal of the American College of Surgeon 2003; (1): 96-106.

33-Arab, Muhammad, Husseini, M., Ranjbar Ezat-Abadi, M., Rashidian, A., Pourreza, A., Vrmqany, M, Tajvar M. Satisfaction and factors influencing satisfaction of inpatient services at Tehran University of Medical Sciences. Journal of Hospital 2000; 9, 3-4 (35): 50-45. . [Persian].

34. Queendom R. Communication skills Test-Revised.Available online by internrt 2004. http://www.Queendom.com/cgi-bin/tests/transfer.cgi.

35. Hossinchari M, Fadakar MM. Effect of University students on communication skills based on the comparison. Quarterly Journal of conduct 2005; 12 (15): 32-21. [Persian].

36. Shakerinia I. Relationship between social support, loneliness and communication skills in women and non-victim victim of cyberspace. The first national conference on family and security. Yazd University. 2013. [Persian].

37. Irurita VF. Factors affecting the quality of nursing care: the patient's perspective. Int $\mathbf{J}$ Nurs Pract 1999; 5 86-94. 
38-Nishaburi M, Raeis Dana N, Ghorbani N, Sadeghi T. Evaluate the quality of nursing care from nurses and patients teaching hospitals in Semnan. koomesh 2000; 12 (2) 38): 134143. [Persian].

38. Mothedyan Tabrizi E, Hamedani Zadeh F, Zigheymat F, Sarhangi F. Investigation of nurses' attitudes toward nursing care of elderly patients. Kowsar Medical Journal 2008; 13 (3): 258-253. [Persian].

39. White AH. Clinical decision making among fourth-year nursing students: an interpretive study. J Nurs Educ 2003; 42(3): 113-20.

40. Gray MA, Smith LN. The qualities of an effective mentor from the student nurses, perspective: findings from a longitudinal qualitative study. J Adv Nurs 2000; 32(6): 15-42.

41. Morse JM, Solberg SM, Neander WL, Bottorff JL, Johnson JL. Concepts of caring and caring as a concept. ANS Adv Nurs Sci 1990; 13(1): 1-14.

42. Aspegren K. BEME Guide No. r: teaching and learning communication skills in medicine-a review with quality grading of articles. Mead Teach 1992; 21(6): 563-70.

43. Wilkinson S, Roberts A, Aldridge J. Nurse-patient communication in palliative care: an evaluation of a communication skills programme. Palliat Med 1998; 12(1): 13-22. 